Scientific Journal Warsaw University of Life Sciences - SGGW

Problems of World Agriculture volume 17 (XXXII), number 4, 2017: 105-110

DOI: $10.22630 /$ PRS.2017.17.4.86

Yuriy Hubeni $^{1}$, Vitalii Boiko ${ }^{2}$, Petro Olishchuk ${ }^{3}$

$1,2,3$ Lviv National Agrarian University, Ukraine,

${ }^{2}$ National Institute for Strategic Studies

\title{
A Retrospective Evaluation of Rural Populations: Social and Economic Challenges, Expectations and Evaluation
}

\begin{abstract}
In 1996 and 2016, respectively, the Independent Creative Group (ICG) conducted a comprehensive sociological study "Economic reform - the eye of the village." The aim of the project was to explore the evaluation of economic reform of rural populations in 5 areas: a) economic reform; b) quality of life and expectations; c) businesses; d) agricultural transformation; e) development of farming. The research was conducted in the form of "sociological fixation" expectations, estimates and other reactions to social challenges. The object of the study was a typical village of the Lviv region.

The study confirmed the simultaneous increase of confidence in economic transformation and the growth of pessimism in the impact of reforms. The rural population understands the goals and objectives of reforms, and supports private property and the market economy. The standard of living has improved significantly, but it does not cover the real expectations of the population. Farmers understand the role and importance of entrepreneurship and accept new business entities. The study showed significant structural changes in the views and assessments of rural residents of the Lviv region. There is obvious public awareness of fundamental lifestyle changes in the countryside.
\end{abstract}

Key words: rural population, economic expectations, reform, agrarian transformation, sociology, Lviv, Ukraine

JEL Classification: O18, P25

\section{Introduction}

Economic decisions, including economic policy, should have an information basis (basis). Besides the standard data of official statistics, information about public attitudes and economic expectations is of great importance in making decisions. Such data, as a rule, are based on data from sociological surveys. The information on understanding and comprehension by the society (population) of real economic, social and political challenges, and the use of this understanding for an adequate and rational correction of evaluations and expectations also have a significant impact.

Monitoring of socio-economic sentiments, evaluations and expectations just in rural areas is especially important in countries with a significant share of agricultural production and rural population. Obviously, the studies with a retrospective nature will be of considerable interest, since they allow us to further evaluate changes and trends. After all,

\footnotetext{
1 Doctor of economic sciences, professor, Department Law \& Business, Lviv National Agrarian University, Volodymyra Velykoho 1, Lviv-Dublany, Ukraine, 80381, e-mail: hubeni@ukr.net

${ }^{2}$ Candidate of economic sciences, Associate Professor, Lviv National Agrarian University; Doctoral student of the National Institute for Strategic Studies, 01133, c. Kyiv, Str. Kutuzova, 18/7. e-mail: v boyko888@ukr.net

${ }^{3}$ Candidate of economic sciences, Associate Professor, Department Law \& Business, Lviv National Agrarian University, Volodymyra Velykoho 1, Lviv-Dublany, Ukraine, 80381, e-mail: petrool@ukr.net
} 
"the analysis of policy uses theory and empirical methods of social sciences to predict the consequences of possible policy options" (Vejmer, Wajning, 1998, p. 22).

\section{Data and methods}

An independent group of researchers conducted a retrospective sociological research "Economic reform through the eyes of the village: 20 years later" in 2016 (Ekonomichna..., 1997). In fact, it was a follow-up research, which was based on the methodology of a similar project conducted in 1996. The idea of both studies was to hold a comprehensive sociological survey of the villagers, that can be considered as a "typical" or representative with a significant approximation. Village (selo) Kryve, Radekhiv district, was chosen for the Lviv region. By the overwhelming group of characteristic features, it could be considered as a representative for the region.

The survey stipulated the following stages:

- Development of research methods;

- Choice of the inhabited locality;

- Advocacy work among the population;

- Selection of respondents;

- Development of questionnaires, tests, etc. Conducting a survey;

- Transfer of information to concerned parties and institutions, the media;

The survey provided for the following sections:
A. General evaluation of the economic reform by rural population;
B. Economic reform and living standards of the rural population;
C. Attitude to entrepreneurship and its manifestations;
D. Evaluation of the agrarian reform and its components;
E. Attitude towards farming.

The individual results of the survey on the first three sections (A, B, C) are the subject of the presentation in this publication.

In the studies carried out in 1996 and 2016 there were insignificant differences in the questionnaire form and the survey algorithm. The survey was carried out by specially trained local residents. The processing of the questionnaires was carried out by the researchers of the Department of Law and Entrepreneurship of the Lviv National Agrarian University. Analytical notes and final presentations were prepared by members of the temporary creative group.

\section{Results}

In 1996, the results were published in the brochure "Economic reform through the eyes of the village. Results and analysis of the sociological survey" (Ekonomichna..., 1997). In 2016, the results were published in the monograph "Economic reform - through the eyes of the village: 20 years later. Results and analysis of a follow-up poll" (Hubeni et al., 2017). Some results can be found on a special page on Facebook (https://www.facebook.com/ ekrefpost/). 
The preliminary results of the survey show that significant changes have taken place in the public consciousness of the rural population of Lviv region. These changes indicate a gradual but consistent implementation of new thinking, the formation of rational evaluations of expectations and an awareness of the challenges of development.

\section{A. General evaluation of the economic reform by rural population}

During the first survey about $75 \%$ of respondents assessed economic reform very negatively, and only $12 \%$ saw it as positive. According to recent studies, the share of negative assessments decreased to $57 \%$, and positive - to $10 \%$.

Table 1. General evaluation of economic reform, survey results, \%

\begin{tabular}{l|rrr}
\hline \multicolumn{1}{c|}{ Question - answers } & 1996 & 2016 & $2016+/$ to 1996 \\
\hline \multicolumn{2}{c}{ How do you estimate the economic reform in general? } & \\
\hline - very positive; & 2 & 6 & +4 \\
- very negative; & 18 & 22 & +4 \\
- it ruined national economy; & 18 & 8 & -10 \\
- it leads to an improvement in the economy; & 10 & 4 & -12 \\
- economic reform goes in the wrong direction; & 39 & 27 & +5 \\
- it's hard to say; & 22 & 27 & +3 \\
- I don't know. & 3 & 6 & \\
\hline
\end{tabular}

Source: Hubeni et al., 2017, p. 28

For 20 years, the number of supporters of "socialism" has significantly decreased, and the share of supporters of its modernization is steadily decreasing.

Table 2. Transformation of socialism, survey results, $\%$

\begin{tabular}{|c|c|c|c|}
\hline Question - answers & 1996 & 2016 & $2016+/-$ to 1996 \\
\hline \multicolumn{4}{|c|}{ Was it necessary to change the economic model of "socialism"? } \\
\hline - yes; & 38 & 58 & +20 \\
\hline- no; & 10 & 5 & -5 \\
\hline - just to improve a bit; & 49 & 20 & -19 \\
\hline - I don't know. & 7 & 18 & +11 \\
\hline
\end{tabular}

Source: Hubeni et al., 2017, p. 29

The results of both studies indicate that rural population in matter of property have been and remain rational, more balanced and more responsible than many politicians and officials. The pluralism of forms of ownership and management today is supported by $62 \%$ of respondents (49\% in 1996).

The majority of respondents in both studies believed that economic problems, crisis phenomena are primarily determined by inept reforms: $60 \%$ of respondents in 2016 and $64 \%$ in 1996. 


\section{B. Economic reform and living standards of the rural population}

Questionnaire B was designed to study the standards of living of rural residents, their consumer expectations, as well as to determine the impact of economic transformations on them. The rural population of Lviv region expressed a clear dissatisfaction with the level of their life during the basic study. No respondent considered his family to be "very rich", "rich", "prosperous", and $40 \%$ of respondents considered their families to be "poor". In a second study, $1 \%$ of the "very rich" and "prosperous" households appeared, the share of the "poor" decreased to $26 \%$ (- 14\%), the most common became "middle-class" families $(63 \%)$. Objective statistical data also confirms that in 2016 the rural population lived twice as better materially than the previous generation.

The growth in the standard of living and the resulting change in the structure of consumption has been confirmed by this simple question:

Table 3. Consumer preferences - food, survey results, $\%$

\begin{tabular}{|c|c|c|c|}
\hline Question - answers & 1996 & 2016 & $2016+/-$ to 1996 \\
\hline \multicolumn{4}{|c|}{ What food stuff do you usually buy? } \\
\hline - bread; & 16 & 83 & +67 \\
\hline - macaroni; & 40 & 79 & +39 \\
\hline - sugar; & 17 & 63 & +46 \\
\hline - dairy products; & 5 & 9 & +4 \\
\hline - alcohol; & 9 & 10 & +1 \\
\hline - cereals; & 81 & 80 & +1 \\
\hline - sweets; & 38 & 29 & -9 \\
\hline - meat products; & 9 & 21 & +12 \\
\hline - coffee, tea; & 71 & 67 & -4 \\
\hline - beverage and juices. & 12 & 3 & -9 \\
\hline
\end{tabular}

Source: Hubeni et al., 2017, p.40.

In 1996, only one of the six families (16\%) had the opportunity (!) to buy bread in trade institutions. Baking bread at home was acceptable for very limited budgets of rural households. And already $83 \%$ of rural households was buying bread in the trading network in 2016. An increase in purchases can be seen almost in all groups of food products. There was a significant increase even for meat purchase $(+12 \%)$.

Improvement of general socio-economic conditions affected their responses to the question of hypothetical use of income growth. If in 1996 the physical survival of rural families was the priority, then in 2016 the improvement of the comfort and living conditions dominated, including better housing.

The follow-up research confirmed not only the obvious positive changes in the standard of living of rural residents, but also showed the special role of economic expectations in evaluating the perception of the socio-economic situation in the country and the level of prosperity of their families. 


\section{Attitude to entrepreneurship and its manifestations}

The task of the questionnaire " $\mathrm{C}$ " during the basic and follow-up polling was to study the attitude of the rural population to entrepreneurship, its manifestations or conditions of conduct. We expected significant changes in the answers, because during the basic research (1996), entrepreneurship in Ukraine, especially in agriculture, only "was getting on its feet".

Follow-up research confirmed the slow stratification of villagers according to the direction of activity. Villagers no longer want the traditional exhausting combination of agricultural labour in the household and the running their own business /hired work. Thus, in particular, the number of respondents who prefers to work for hire with a simultaneous housekeeping is decreasing $(-18 \%)$. The same percentage of respondents agrees either for only hired work $(+13 \%)$ or starting own business $(+5 \%)$. Our empirical observations confirm that rural people working for hire tend to be similar to urban workers in economic behaviour and motivation. The Ukrainian village is on the edge of significant structural and usual changes.

The attitude of rural people to wealth and the desire to get rich is also interesting:

Table 4. Wealth as a dream of the rural population, survey results, $\%$

\begin{tabular}{|c|c|c|c|}
\hline Question - answers & 1996 & 2016 & $2016+/-$ to 1996 \\
\hline \multicolumn{4}{|c|}{ Do you want to become rich? } \\
\hline - yes, by all means; & 4 & 5 & +1 \\
\hline - yes, but only by fair means; & 49 & 43 & -6 \\
\hline - I just want to improve slightly the quality of life; & 51 & 49 & -2 \\
\hline - no, I don't want to be rich; & 4 & 2 & -2 \\
\hline - I don't know. & 2 & 1 & -1 \\
\hline
\end{tabular}

Source: Hubeni et al., 2017, p. 47.

As we see, the villagers are conservative and cautious, they want just to improve their material situation slightly (49\%), or they are looking to wealth got only "by fair means" $(43 \%)$

A positive change in the sociological sentiments is the recognition of the usefulness and positive nature of entrepreneurship as a phenomenon. During the follow-up poll, the thesis that "business (entrepreneurship) is useful and necessary for the state and society" was supported by as many as $68 \%$ of villagers $(+24 \%)$. It is obvious that the public discussion and the empirical basis are reflected in the minds of the villagers and they increasingly understand the essence of entrepreneurship and its manifestations. Therefore, it is natural that the thesis about the "harmfulness of entrepreneurship" becomes less popular $(8-10 \%)$.

Understanding of entrepreneurship and its perception by rural population has significantly improved. Entrepreneurial thinking, the reflection of the market economy in the public consciousness find development, understanding and support. The majority of rural residents understand the special role of the environment in business development, they accept competition, variety of subjects and non-agricultural entrepreneurship in their own village. They have no doubts about the usefulness of developing entrepreneurial initiatives 
for the state and society. On the other hand, they realize their position in the "triangle of modern economy."

\section{Conclusions}

The conducted studies confirm the formation of rational thinking among the villagers about the organization of economic relations and the functioning of the agricultural land market. They expressed an interest in taking into account their opinions and expectations when carrying out economic reforms, especially agrarian ones.

Villagers, represented by the rural population of Lviv region, underwent substantial development in their awareness of the essence of economic reform. They feel or know the goal of economic transformation, and are aware of the challenges that the new economy and democracy are mounting.

Public sentiments are generally favourable for the continuation of reforms and modernization. Villagers feel the need of social dialogue. They are distinguished by the growth of rational expectations, the optimization of behaviour and the hierarchy of priorities.

\section{Bibliography}

Ekonomichna reforma - ochyma sela: rezul'taty ta analiz sotsiolohichnoho opytuvannya. (1997). Lviv, LDAU. https://www.facebook.com/ekrefpost/

Hubeni, Y.E., Bitter, O.A., Bondarchuk, V.V., Zhars'ka, S.Y., Topishko, I.I., Yatsiv, I.B. (2017). Ekonomichna reforma - ochyma sela: 20 rokiv potomu: Rezul'taty ta analiz povtornoho sotsiolohichnoho opytuvannya. (ed.) Y. Hubeni, L'viv, NVF "Ukrayins'ki tekhnolohiyi".

Panina, N.V. (1996). Tekhnolohiya sotsiolohichnoho doslidzhennya: Kurs lektsiy. Kyiv, Naukova dumka. Vejmer, D.L., Wajning, E.R. (1998). Analiz polity`ky`: Koncepciyi i praktyka. Kyiv, Osnovy.

Acknowledgements: Basic research (1996) was carried out with the financial support of the International Renaissance Foundation. Follow-up research (2016) was carried out as an independent research project funded by a group of private sponsors. The general direction of the project corresponds to the theme of scientific research of the Lviv National Agrarian University. 